\title{
Public Private Partnership E-Government in Improving Service Quality in Community Health
}

\author{
Muhammad Haikal SHAHAB ${ }^{1}$, Darius ANTONI ${ }^{2 *}$, and Muhammad AKBAR ${ }^{3}$
}

\author{
${ }^{1}$ haikal.pusri@gmail.com, Universitas Bina Darma Palembang,Indonesia \\ ${ }^{2}$ Darius.antoni@binadarma.ac.id, Universitas Bina Darma Palembang,Indonesia

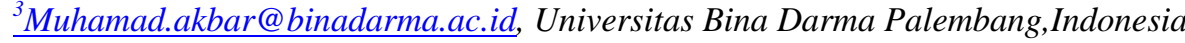

\begin{abstract}
Advances in the use of information technology (ICT) have greatly facilitated the development of electronic government (E-Government) throughout the world. The benefits of this development can improve the quality of services to the community through aspects of user approval, efficiency, openness, and responsiveness. However, the lack of skilled human resources and limited government capacity in terms of e-government development. Public private partnership (PPP) is a solution to overcome problems, challenges and obstacles faced by the government in realizing e-government development goals. PPP is expected to improve the goal of e-government development, namely to improve the quality of services to the public through the private sector in public health services in the city of Palembang.
\end{abstract}

Keywords: PPP, E-Government, Palembang, public health

\section{INTRODUCTION}

Advances in the use of information technology (ICT) have greatly facilitated the development of electronic government (E-Government) throughout the world [1] [2]. Resulting in a transformation that is very useful for the delivery of public services that are centralized from the government to the delivery of services that are centered on citizens [3]. Governments around the world are trying to improve services by using E-Government to change the delivery of their public services, change greater interactions between citizens and government, streamline two-way communication between citizens and government, increase the efficiency of public organizations, and save on tax costs [4] make it easier for the public to access services, eliminate distance, expand service coverage, and save costs and time [5], [6], [7]. In fact, E-Government is seen as a very effective way to create public value for citizens (United Nations, 2003).

Palembang is the capital of the province of South Sumatra and is the second largest city after Medan. Palembang is one of the cities in Indonesia that is considered modern because it has implemented E-Government for public services. E-Government Forms used are websites and mobile. A website is a collection of pages on a domain on the internet that aims to interact with one another and can be accessed widely through the front page (front page) using a browser via the website URL.

While cellphones are adjectives meaning they can be moved, free, can move easily and easily. But mobile can be interpreted as an object that has high technology that can move without using cables. One example is smartphones, Personal Digital Assistants (PDAs), and tablets.

Although the Palembang city government has implemented many E-Government to serve the community, the number of E-Government that has been implemented is not sustainable due to changes in the era of government, the system follows the government's wishes and needs. So the old system will be discarded and replaced with a new system to match the era of government, causing less efficiency on the system side, and the time of change from the old system to the new system.

Public Private Partnership (PPP) is the most popular way to focus the government's role on service actions to the community by cracking down on puskesmas and hospitals that are not in accordance with service standards. While the role of PPP is to develop a system that will be developed based on the needs and problems faced by patients who have been treated in hospitals, health centers. However, there needs to be indicators in evaluating the performance and quality of system services conducted by PPP.

The concept of public value is the most popular tool in evaluating the performance and quality of public services [8]. this concept provides an inclusive framework in examining the performance of public organizations in creating public value for citizens [8], [9], [10]. By using this concept, the efficiency of public organizations can be assessed [8], [10]. E-Government offers improved services for the government to improve the delivery of public services through the automation of various public service processes (Kearns, 2004). With the rapid development of E-Government, adopting the concept of public value to evaluate the performance of E-Government from the perspective of citizens is not only appropriate but also necessary.

\section{LITERATURE REVIEW}

\section{E-Government}

E-Government is a component of government information and communication technology systems in the exchange of information to improve governance [11]. Benefits of implementing E-Government [12]. These benefits include:

- In order to improve the quality of government services to the public, the main thing is in terms of effectiveness of performance, and also efficiency in various fields of state life. 
- Openness in controlling and also accountability in government administration in order to apply the concept of Good Corporate Governance

- To reduce the amount of administrative costs, interactions and relationships also occur by the government for the benefit of daily activities.

\section{Understanding Public Private Partnership E- Government}

Public Private Partnership (PPP) is an agreement between public bodies namely national, state (local) companies and private companies in providing infrastructure services that have traditionally been provided by the government [13]. PPP provides an appropriate opportunity for public institutions to partner with private organizations in government-initiated projects. The main feature of the PPP infrastructure is the private partners who invest in public infrastructure such as developing an E-Government system and providing related non-core services. The government remains responsible for providing core services. The government and the private sector work together under long-term arrangements.

The use of PPP changes the role of government. This change came from a developer who is a service provider. An important feature of PPP change is the risk allocation for partners, namely private or public institutions that are best able to manage that risk. For example, public bodies will be responsible for serving in improving service quality, while private partners are best prepared to face the risk of problems with system development because of their ability to manage construction procedures, incorporating the latest technological innovations [14]. The benefit of using PPP is the potential value of money, initial project delivery. benefit from innovation, eliminating the need to borrow to finance infrastructure investment and access to better services. The last few decades have witnessed many PPP applications in the implementation of E-Government services. The maturity of ICTs and their dominance since the beginning of this century have enabled public institutions to work with IT partners in the private sector to provide electronic services to citizens, which complements traditional ways of providing these services by the government to their stakeholders.

\section{The Concept of Public Value}

The concept of public value is a popular tool in evaluating the performance of public services [8]. This concept provides an inclusive framework for examining the performance of public organizations in creating public value for citizens [9], [10]. By using this concept, the efficiency of public organizations can be assessed [8], [10]. E-Government offers many opportunities for governments to improve the delivery of public services through the automation of many public service processes (Kearns, 2004). With the rapid development of E-Government, adopting the concept of public value to evaluate the quality of PPP E-Government requires the right concept. Appropriate conceptual framework for evaluating the public value of E-Government through user orientation, organizational efficiency, openness, responsiveness.

\section{User Orientation}

User Orientation focuses on government services for citizens in providing E-Government services. Effective delivery of E-Government services requires change and adoption in a citizen-centered approach to E-Government [15]. In line with this, citizens' perceptions about the user friendliness of government websites [16], simple and concise website addresses [8], from one website with links to other websites, from one single website to provide all information, look and feel all government websites, and frequently asked questions [19] important to measure government services to citizens in providing EGovernment services.

\section{Efficiency of Public Organizations}

Public Organization Efficiency is a key indication of public value through E-Government as measured by organizational efficiency, responsiveness, openness, and environmental sustainability [18]. E-Government is used in increasing the efficiency of public organizations by cutting processing costs, making strategic connections between government institutions. In this context, the efficiency of public organizations is determined through the development of better ICT infrastructure, sharing public information, redesigning public functions to empower public sector staff, and cutting staff surpluses. Because public organizations use money for staff taxpayers, citizens appreciate the increased efficiency of public organizations through E-Government which results in savings [4].

\section{Openness}

Openness refers to transparency of public services [19]. This shows the extent to which an organization has updated its decision processes and procedures, and performance information in a timely manner [20]. Public organizations can be open by publishing what needs to be disclosed, for example, public policies and information on the budget [19]. Publish drafts of online public policies by the government for public consultations, public organization budget disclosures, and online spending to show accountability, issue online tenders by public organizations to increase transparency, citizens' ability to make online complaints, and the existence of organizational frameworks and contact information for public officials online is a leading indicator of openness [18].

\section{Responsiveness}

Responsiveness is directed to the extent to which public organizations can meet public demands [19]. In EGovernment, responsiveness is examined through citizens' perceptions of how public organizations respond to their questions through E-Government access channels, the ability to track the status of applications submitted to public organizations, and through the extent to which citizen certificates are displayed online. One example is the Sri Lankan citizen charter regarding documents issued by the government in setting thn e minimum number of days required by certain public organizations to process applications or provide services to citizens. 


\section{RESEARCH METHODOLOGY}

\section{Research Data}

The development of concepts in this study refers to the theory of E-Government and Public Private Partnership. Data collection in this study was carried out through a series of literature reviews, interviews, and observations. Participants in this study were patients in the city of Palembang who had been treated in a hospital or puskesmas in the city of Palembang, and related stakeholders in developing public and private public partnerships. The research method used is descriptive because it examines objects or conditions in the present [21]. Data collection is based on primary data and secondary data, where primary data is obtained through interviews with patients who have been treated in hospitals, health centers in the city of Palembang. Secondary data obtained through various reports and publications relevant to research then continued with the development of the system using the prototype method.

\section{Interview}

Primary data collection through direct interviews with patients who have been treated in hospitals or health centers in the city of Palembang. Based on the results of interviews conducted with 10 patients who have been treated in hospitals or health centers in the city of Palembang, there are various problems and complaints faced by patients during treatment at the hospital, as follows:

Table 1 Public Complaints Interview

\begin{tabular}{|c|c|}
\hline Interview & Problem \\
\hline Patient 1 & Slow Service \\
\hline Patient 2 & Lack of Information at the Hospital \\
\hline Patient 3 & $\begin{array}{l}\text { There is no place for complaints against public } \\
\text { health services }\end{array}$ \\
\hline Patient 4 & $\begin{array}{c}\text { The slow pace of government action at the } \\
\text { hospital }\end{array}$ \\
\hline Patient 5 & Complaints about Website Confusion \\
\hline Patient 6 & There is no place to ask \\
\hline Patient 7 & $\begin{array}{c}\text { The government is less open in taking action } \\
\text { against hospitals }\end{array}$ \\
\hline Patient 8 & $\begin{array}{l}\text { Complaints are not processed, so there is no } \\
\text { guilty effect on the hospital }\end{array}$ \\
\hline Patient 9 & $\begin{array}{l}\text { Slow response from the Government in cracking } \\
\text { down on guilty hospitals }\end{array}$ \\
\hline Patient 10 & $\begin{array}{l}\text { The flow of hospital services in care is confusing } \\
\text { and complicated. }\end{array}$ \\
\hline
\end{tabular}

\section{Design}

Often customers determine general objectives for the software, but do not identify detailed requirements for features and functions [19]. On the other hand, development may be uncertain in terms of the efficiency of an algorithm, the adaptation of the operating system, or the form of interaction between humans and machines must be the same. design and development based on the needs and complaints of people obtained through interviews. There are five stages of development that suit this need, as follows:

- Communication. The developer takes respown from patients who have been hospitalized, then determines the format and needs of all software, identifies all needs, and describes the system to be made.

- $\quad$ Quick Plan. Create and build a simple software prototype that will be developed in accordance with the results of a communication interview with patients conducted in the previous stage.

- Modeling Quick Design. Create interface designs using photoshop software. So that the display design is clearer and understood by the public.
The completed prototype will then be handed over to the community and the community will then conduct an evaluation and attract the interest of the community.

- Construction of Prototyping. At this stage, prototyping will be agreed and agreed upon by the public, namely using web-based programming using PHP.

- Deployment Delivery and Feedback. At this stage the system is created and then handed over to the community and asks for a reply to the community. If it is in accordance with the wishes of the community, the development phase by PPP is complete. However, if it is not suitable and there are many complaints from the community, the system is developed again so that the system can meet the needs of the community.

\section{RESULTS AND DISCUSSION}

According to the results of a conceptual framework study based on interviews conducted with patients who have been hospitalized, puskesmas. To evaluate the public value of EGovernment and develop a better E-Government, 
indicators need to be improved in improving service quality. The adoption of this indicator is used in the development of E-Government in the field of public health in the city of Palembang. There are four indicators of success in addressing the problems and complaints faced by the community in improving the quality of services for patients seeking care in hospitals and increasing public confidence in the government, namely:

\section{User Orientation}

There is a need to address a simple website that makes it easy for people or patients who have been hospitalized or puskesmas to make complaints about the services provided by hospitals and puskesmas. This also requires window information from the website regarding health services to hospitals or health centers in the city of Palembang. And have information about the appearance of services to hospitals or health centers. Like Figure 1 below.

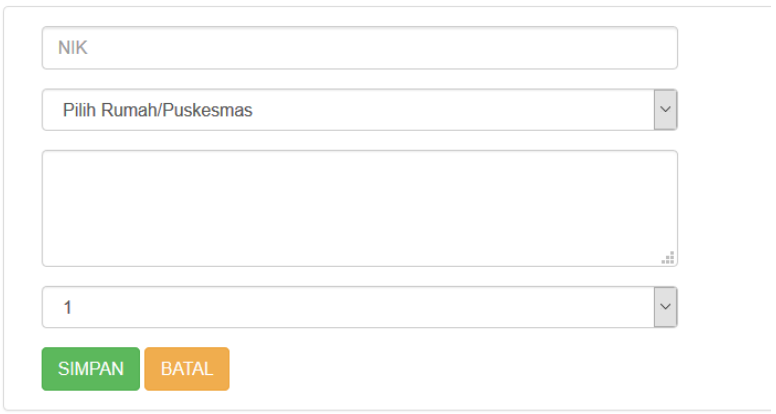

Figure 1 Display Patient Complaints

\section{Organizational Efficiency}

There needs to be efficiency in the organization by focusing on PPP as a system developer and the government as a provider of action against hospitals or puskesmas when violating, based on hospital calculations. calculation of public services is needed so that the public or prospective patients can find out the quality of the hospital or health center. With this service, public trust in government is increasingly based on hospital assessments provided by patients who are happy or disappointed to see hospital care. Organizational efficiency can also be done by sharing the tasks of system developers with PPP and the core by the government. Indirectly, the division of tasks can benefit the government because it can learn about the system and increase knowledge when problems or obstacles occur. The system created as a government access to provide measures.

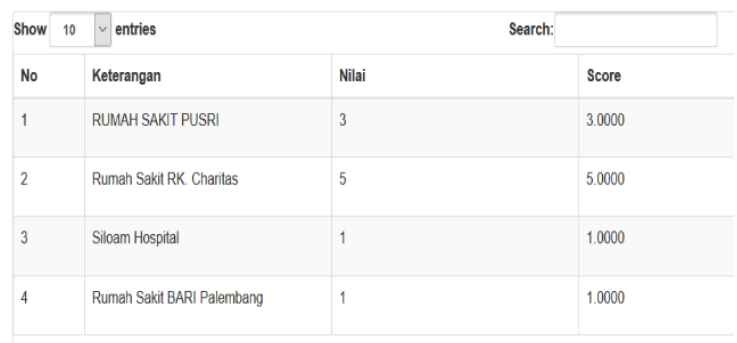

Figure 2 Hospital Rating (Government Access)

\section{Openness}

Openness to patients and the public by displaying complete information about hospitals or health centers in the city of Palembang. In addition, information in the form of telephone, address, weight assessment of hospitals or health centers so that people can find out the quality of hospitals in terms of service.

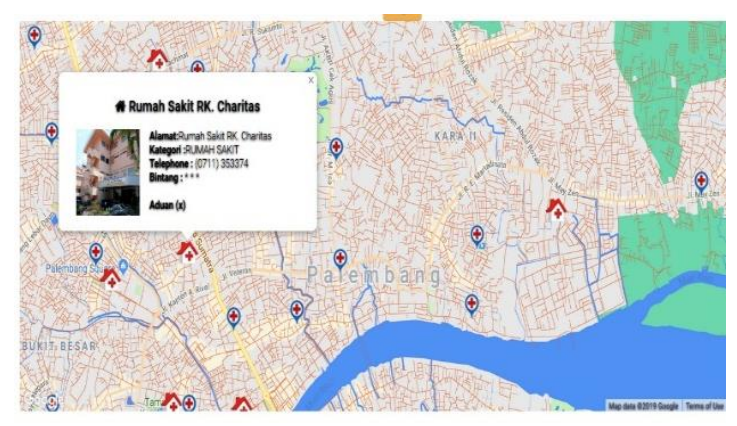

Figure 3 Complete Information Display

\section{Responsiveness}

Responsiveness is a step taken by the government in meeting the demands of society. Requests from the public or patients can be maximized with a deadline for patient complaints. Responsive ability can be through the ability to ask questions online, meaning that people can submit complaints or questions about the hospital or puskesmas that they want to comment on. Or a follow-up email to be asked after filing a complaint, the public can also provide input and questions about the problem at hand.

\section{CONCLUSION}

This research presents the development of e-government services to increase public trust in government. This system was developed by reviewing previous research, which was collected as a reference in the development of health services in the city of Palembang. This study concludes that e-government services in increasing public trust can be improved through four indicators namely user orientation, organizational efficiency, openness, and responsiveness. 


\section{REFERENCES}

[1] Deng, H. (2008). Towards objective benchmarking of e-government: An inter-country analysis. International Journal of Transformational Government: People, Process and Policy, 2(3), 162-176.

[2] Lee, J. (2010).10 year retrospect on stage models of e-Government: A qualitative meta-synthesis.

Government Information Quarterly, 27(3), 220-230.

[3] Al-Sobhi, F., Weerakkody, V., \& Kamal, M. M. (2010). An exploratory study on the role of intermediaries in delivering public services in Madinah City: Case of Saudi Arabia. Transforming Government: People, Process and Policy, 4(1), 14-36.

[4] Gauld, R., Goldfinch, S., \& Horsburgh, S. (2010). Do they want it? Do they use it? The demand-side of egovernment in Australia and New Zealand. Government Information Quarterly, 27(2), 177-186.

[5] Badri, M. A., \& Alshare, K. (2008). Path analytic model and measurement of the business value of egovernment: An international perspective. International Journal of Information Management, 28(6), 524-535.

[6] Beynon-Davies, P. (2005). Constructing electronic government: The case of the UK Inland Revenue. International Journal of Information Management, 25(1), 3-20.

[7] Jaeger, P. T., \& Thompson, K. M. (2003). Egovernment around the world: Lessons, challenges, and future directions. Government Information Quarterly, 20(4), 389-394.

[8] Moore, M. H. (1995). Creating public value: Strategic management in government. London: Harvard University Press.

[9] Alford, J., \& O'Flynn, J. (2009). Making sense of public value: Concepts, critiques and emergent meanings. International Journal of Public Administration, 32(3-4), 171-191.

[10] Kelly, G., Mulgan, G., \& Muers, S. (2002). Creating public value: An analytical framework for public service reform. Retrieved October 15, 2008, from. http://www.

allamreform.hu/letoltheto/kozfeladatok/kulfoldi/public value2.pdf.

[11] Antoni, D., Akbar, M., \& Fatoni, F. (2018). Electronic Government Rukun Tetangga Model, 64-73.

[12] Antoni, D., Herdiansyah, M. I., \& Akbar, M. (2017). Critical factors of transparency and trust for evaluating e-government services for the poor. Second International Conference on Informatics and Computing (ICIC) (pp. 1-6). Papua: IEEE.
[13] Center for Democracy and Technology (2006) "Public-Private Partnerships, e-Government and Privacy", Working Paper November 2006, http://www.cdt.org.

[14] Australian Government (2002) Public-Private Partnerships: An Introduction, Australia: Department of Parliamentary Library

[15] Chang, C. C., Chen, Y. F., \& Liao, K. H. (2009). A triple-diamond framework for the assessment of egovernment in delivery service quality. Proceedings of the International Conference on New Trends in Information and Service Science, 2009, doi: 10.1109/NISS.2009.179.

[16] Yoo, B., \& Donthu, N. (2001). Developing a scale to measure the perceived quality of internet shopping sites (SITEQUAL). Quarterly Journal of Electronic Commerce, 2(1), 31-47.

[17] Papadomichelaki, X., \& Mentzas, G. (2009). A multiple-item scale for assessing egovernment service quality. In M. A. Wimmer, H. J. Scholl, M. Janssen, \& R. Traunmuller (Eds.), Lecture notes in computer science: 5693. EGOV 2009. (pp. 163-175) Berline: Springer-Verlag.

[18] Karunasena, K., \& Deng, H. (2010). Exploring the public value of e-government: An empirical study from Sri Lanka. Proceedings of the 23rd Bled e-Conference e-Trust: Implication for the individuals, enterprises and society Retrieved from.

http://aisel.aisnet.org/bled2010/21/

[19] Jorgensen, T. B., \& Bozeman, B. (2007). Public values an inventory. Administration \& Society, 39(3), 354-381.

[20] Wong, W., \& Welch, E. (2004). Does egovernment promote accountability? An International Journal of Policy Administration, and Institutions, 17(2), 275-297.

[21] Nazir, M. (2005). Metode Penelitian. Jakarta: Ghalia Indonesia. 